\title{
Approach in Strengthening Patriotism among Students Through Patriotism-Based Courses
}

Ku Hasnita Ku Samsu, Zatul Himmah Adnan, Mohd. Mahadee Ismail, Lee Yok Fee, Arfah Ab Majid \& Ratna Roshida Ab Razak

To Link this Article: http://dx.doi.org/10.6007/IJARBSS/v11-i12/11942 ～DOI:10.6007/IJARBSS/v11-i12/11942

Received: 18 October 2021, Revised: 21 November 2021, Accepted: 30 November 2021

Published Online: 16 December 2021

In-Text Citation: (Samsu et al., 2021)

To Cite this Article: Samsu, K. H. K., Adnan, Z. H., Ismail, M. M., Fee, L. Y., Majid, A. A., \& Razak, R. R. A. (2021). Approach in Strengthening Patriotism among Students Through Patriotism-Based Courses. International Journal of Academic Research in Business and Social Sciences, 11(12), 2160-2172.

Copyright: (c) 2021 The Author(s)

Published by Human Resource Management Academic Research Society (www.hrmars.com)

This article is published under the Creative Commons Attribution (CC BY 4.0) license. Anyone may reproduce, distribute, translate and create derivative works of this article (for both commercial and non0-commercial purposes), subject to full attribution to the original publication and authors. The full terms of this license may be seen at: http://creativecommons.org/licences/by/4.0/legalcode

Vol. 11, No. 12, 2021, Pg. 2160- 2172

Full Terms \& Conditions of access and use can be found at http://hrmars.com/index.php/pages/detail/publication-ethics 


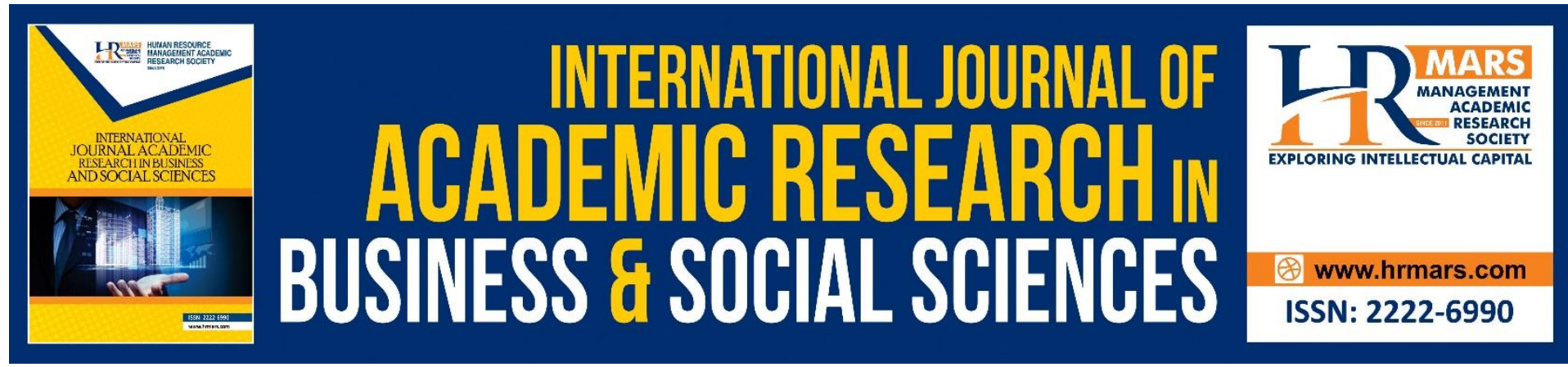

\title{
Approach in Strengthening Patriotism among Students Through Patriotism-Based Courses
}

\author{
Ku Hasnita Ku Samsu, Zatul Himmah Adnan, Mohd. Mahadee \\ Ismail, Lee Yok Fee, Arfah Ab Majid \& Ratna Roshida Ab \\ Razak \\ Department of Government and Civilization Studies, Faculty of Human Ecology, \\ Universiti Putra Malaysia, 43400 Serdang, Selangor. \\ Email: hasnita@upm.edu.my
}

\begin{abstract}
Patriotism-based courses have been thought to Malaysian students since they were in primary school until they reach tertiary education. Certainly, the general objective of those courses is to inculcate as well as to strengthen patriotism in students. Unfortunately, these courses are always seen as subjects that are boring and dull by the students due to the need to memorise facts and historical events. The combination of quantitative and qualitative nature of this study is therefore aimed to identify the teaching and learning approaches that can attract the students' interest for this kind of nation building courses, thereby making the learning process fun yet effective. Accordingly, the sample has consisted of 800 respondents from public universities who have taken a Malaysian Nationhood course, as their experiences are important to achieve the objective of this study. The findings were analyzed based on the respondents' feedback on the teaching and learning methods to attract students to patriotism-based courses that were categorized into six approaches, namely, teachercentered, student-centered, interactive, constructivist, collaborative and indirect. This classification is important to assist the educators in choosing the appropriate approach to attract students to patriotism-based courses. So far, there are no studies that have categorized teaching and learning approaches based on the respondents' feedback.

Keywords: Patriotism, Nation Building Courses, Teaching and Learning Approach, Patriotism Education, Tertiary Education

\section{Introduction}

Initiatives and efforts have been undertaken by the government at various levels of the educational institutions in Malaysia to foster patriotism among Malaysians from time to time through the teaching and learning of patriotism-based courses. For example, at the primary and secondary levels, there are several patriotism-based subjects that have been taught such as History and General Studies (Pengajian Am), while at the higher education level, some public universities such as Universiti Putra Malaysia (UPM), Universiti Utara Malaysia (UUM)
\end{abstract}


and Universiti Pendidikan Sultan Idris (UPSI) have made the Malaysian Nationhood course as compulsory. In addition, Philosophy and Current Issues as well as Appreciation of Ethics and Civilization courses have been introduced and become compulsory to all institutions of higher learning in 2019 to replace the Ethnic Relation and Islamic Civilization and Asian Civilization (TITAS) courses. This situation indicates that Malaysians have undergone a thorough political socialization process on the elements of nationhood through patriotism-based subjects and courses starting at children's level to teenagers, and adults. In fact, the value cultivation process is also implemented through co-curriculum activities such as Scout, Pandu Putri, Police Cadet, Reserve officer Training Unit (PALAPES), Police Undergraduate Volunteers Force (SUKSIS), and others. Thus, based on this statement, the spirit of patriotism that is possessed by every citizen should always be vibrant from time to time because the process of cultivating the values has occurred continuously as long as they are students.

However, the situation that exhibited the collapse of patriotism among the students portrayed as if the patriotism education that they had gone through had not succeeded in shaping them as good and patriotic citizens. This can be traced through the various media reports about the people's attitude towards being unpatriotic, such as glorifying communist leaders by displaying caricatures of the communist leaders' faces on cups and pictures of wall decorations at restaurants in Malacca, Penang and Johor (Diyanatul, 2021), albeit the fact that Malaysia prohibits communist ideology. Thus, such an attitude clearly challenges the sovereignty of the country. Similarly, the issue of insulting the Malaysian flag with a fivepointed star which was hoisted when the national anthem was played during the opening ceremony of the $28^{\text {th }}$ Malaysian Basketball Association (MABA) in Kuala Lumpur (Azizah, 2019). The unconverted excuse as alleged by the President of the Malaysian Basketball Association (MABA), Datuk Lua Choon Han should be unacceptable because as a Malaysian he and his team members need to be concerned and sensitive to issues that concern the sovereignty of the country. This has been supported by Professor Dr. Teo Kok Seong, Felo Utama of the Institute of Ethnic Studies (KITA), Universiti Kebangsaan Malaysia (UKM) who has confirmed that the act of hoisting the Malaysian flag with a five-pointed star has been intentional. This is an irresponsible action by the Malaysian Basketball Association (MABA) that can be considered as rude and ridiculing the country (Suraya, 2019).

Notably, the issues that have been presented are only a few examples, there are many more issues of the collapse of patriotism that have occurred. However, the issues will not be discussed in depth in this paper as the main emphasis will be focused on the question as to 'Why is this happening?'. Generally, this problem should not occur because those who are involved with the unpatriotic issue has gone through the process of formal patriotism education at the primary, secondary and higher education levels. In this regard Yong (2013) has pointed out that patriotism-based subjects that are taught are often considered by most students as boring because they need to remember historical facts. Therefore, if such an attitude is present in the students, how can the cultivating and strengthening of patriotism be implemented? In this regard, the teaching and learning aspects in the classroom are one of the main catalysts in increasing students' interest in the related subjects or courses. As such, instructors should do their best to attract students to the subject in order to achieve the learning objectives. Therefore, this study will examine the approach that should be used by the instructor to attract students to appreciate patriotism-based courses or subjects. 


\section{The Importance of Patriotism}

Patriotism refers to the pride and love of the country and the willingness of every citizen to sacrifice everything they have for the sake of the country (Curti, 1946; Berns, 1997). Hence, if one feels that one is patriotic, then the question for self-reflection should be, 'Is he willing to sacrifice for the sake of the beloved country?' The sacrifices that are intended are not only to sacrifice lives against the real enemy, but more than that they include time, energy, fundamental freedom, finance and so on. If the answer is 'yes' then one's confession shows true love to the motherland. If the answer is the other way around, then the value of one's love for the country can be questioned. Indeed, love requires sacrifice. If it is just love without being accompanied by the ability to sacrifice, then the level of true love has not yet been achieved. In this regard, the future of the country depends on the willingness and ability of each citizen to sacrifice his or her personal interests in order to ensure that whatever the country's desire for the good of all citizens, is achieved. Thus, in order to encourage all citizens to have a high level of patriotism, the leaders of the country must set a good example by setting aside personal interests and prioritizing the interests of the community and the country. If the leaders and the citizens have a high level of patriotism, definitely the agenda to develop society and the country will be easier to implement.

To achieve this goal, egocentric patriotism is seen as appropriate for the people including the leaders. According to Primoratz (2002), egocentric patriotism refers to a citizen's feelings of love and loyalty to his country because 'It is his country'; it means that whatever happens to his country be it good or bad, the country has to be defended because it is one's country. Thus, citizens who possess this kind of patriotic spirit will be willing to sacrifice and pour out all feelings of love and loyalty to the country without expecting any returns, benefits or privileges from their motherland. In other words, patriotism is seen as more honest and sincere. However, egocentric patriotism can form reckless patriotism that tends to make a person be obsessed with his or her country. Reckless patriotism can trigger an ethnocentrism, which refers to an ethnic group that feels that their group is superior to other ethnic groups (Johnson, 2000; Motyl, 2001). If this situation occurs, patriotism of this type can divide the people and thus have a negative impact on the country. In this regard, true patriotism should be limited and balanced with moral values and knowledge as borderlines. Such patriotism is known as fair patriotism (Mohd, 2005). Correspondingly, the elements of morality and knowledge that limit patriotism can prevent the triggering of extreme emotional attitude towards the country as well as enabling the combat of ethnocentrism. Therefore, the patriotic spirit can be positioned in the right place by relying on the historical experience and traditions of the motherland. A citizen who has fair patriotism will support all efforts made by the government for the prosperity and well-being of the country. Such a situation should have a positive impact on the overall development of the country in all aspects of life. In this context, a patriotic spirit does not exist within a citizen naturally, it should be nurtured and fostered through education either formally or informally (Ku Hasnita and Haizam, 2011). Therefore, formal patriotism education through educational institutions is seen as capable to give a more positive impact on inculcating the spirit of love for the country through its curriculum and cocurricular activities that are more organized and systematic.

\section{Literature Review}

There have been various past studies that have shown the collapse of the patriotic spirit among the younger generation. For instance, the study of Ku Hasnita et al (2020) have found 
that the patriotic spirit of the younger generation in Malaysia is increasingly worrying as there is blatant insult for the traditional elements in the Federal Constitution through the social media; the insult covers aspects of the national language, royal institutions and also Islam as the religion of the Federation. This situation exposes opposition to the element of the national identity that can be found in the Federal Contitution. Aishah et al (2020) has also found that the level of patriotism of Malaysian youth is still low. This is due to the lack of understanding of the meaning of nationhood and the lack of knowledge that is related to the country. Similarly, the National Patriotism Index study that has been conducted by the Biro Tata Negara has found that the index score for student patriotism in higher education institutions is low, i.e., at 3.8 (Tengku, 2015). This scenario is very worrying and should be a concern for the citizens as well as the leaders as it involves the younger generation who will inherit this country in the future.

In this context, there are numerous studies that have been conducted to examine the methods and strategies of strengthening patriotism among the younger generation. For example, Mahadee et. al (2014); Hairul et. al (2013); Tarmizi et. al (2010) have discussed the method of strengthening patriotism through the National Service Training Program (PLKN). PLKN is a government program that has been launched on 16 February 2004. The target group consists of teenagers who have completed their studies at the secondary school level; the program focuses on strengthening patriotism among the younger generation through character building modules, nationhood, community and physical services, and is also enhanced by emphasising the spirit of patriotism and volunteerism. However, PLKN has been abolished in 2018 (Rizanizam, 2018). In this regard, Saifuddin (2005) has explained that the spirit of patriotism among the younger generation can be nurtured through the following approaches: firstly, patriotism education which focuses on two aspects, namely basic programs such as in the form of seminars and courses in addition to side programs such as camping, running and expeditions; second, the application of patriotism is implemented through programes that are organised by the government such as Rakan Muda; third, the cultivation of patriotism through electronic media such as broadcasting patriotic songs in local radio and television stations. This has been supported by Karlin (1975) who has stated that certain activities such as watching television programs, reciting a pledge of allegiance, essay writing competitions are able to instil and strengthen patriotism among the younger generation.

In Malaysia, efforts to strengthen patriotism through formal education, especially through educational institutions have long been implemented. Various patriotism-based subjects have been taught at numerous levels in educational institutions such as at the primary, secondary and higher learning institution to foster and strengthen patriotism such as Local Studies (Kajian Tempatan), History, Civic Education and Citizenship, General Studies (Pengajian Am), Malaysian Nationhood and Ethnic Relations. Manzo (2001) has also acknowledged the importance of civic learning in fostering patriotism after the tragedy of the attacks in New York on September 11, 2001. In this case, any threat or current events that occur in the country can also reflect the patriotism of the citizens based on their response. This can be proven by the study of Vail (2002); Gehring (2002) which have found that after the attack on the World Trade Centre in New York, United States on September 11, 2001, the leaders have begun to realize the need to strengthen patriotism among the American citizens. Since the event, schools have started to actively promote patriotism among the students by 
emphasizing civic education, flying the American flag and singing patriotic songs. In addition, Chu and Couper (2003) have discovered that the patriotism-based subjects that are taught in school are able to increase the awareness of patriotism among the students. For instance, the History subject has been introduced in schools to ensure that the younger generation can fully understand the origins of the establishment of Malaysia and the Federal Constitution. Salbiah (1995) have stressed that teaching the history subject is important in inculcating the spirit of loyalty to the country, love for the homeland as well as to raise concerns about the various things that are happening in the country. Likewise, the study by Ruddin et. al (2005) explains that the subject of History can be an important tool for producing people who are loyal and proud of their country's culture and heritage. Nussbaum (2012) has also emphasized that the teaching of history that is related to the achievements of national leaders can also inspire students to be patriotic.

Hence, the appropriate teaching pedagogy will give a positive impact on the nurturing and appreciation of the students' patriotic spirit. In this regard, the planning of teaching and learning activities should be carried out carefully and should involve the students actively. Mokhtar (2015) has stressed that in order to inculcate patriotism in the students, the teachers should teach sincerely and earnestly. They themselves need to appreciate the content of the subject that is taught in order to be emulated by the students. Based on the knowledge and understanding of the historical aspects of the country for example, students will be guided to analyze and evaluate historical facts rationally. As a result of the understanding and an appreciation of the country's history, the students can build a patriotic spirit in themselves. Thus, the role of the teachers is important to ensure that students are able to master the subjects well (Eggen and Kauchak, 1993). In general, there are many teaching and learning approaches that can strengthen the students' understanding and mastery of the subjects that have been taught, such as teacher-centered, student-centered, interactive, constructivist, collaborative and indirect (Hoque, 2016). In this case, if the approach is applied correctly it will help to attract students to the subjects that are perceived to be very boring.

\section{Research Methodology}

The design of this study involves a mixture of qualitative and quantitative methods. At the beginning, the study has been conducted in a qualitative way by assuming that each individual (student) is able to interpret the current scenario independently. Thus, the nominal group technique (NGT) is applied to obtain data on the method of fostering the patriotic spirit through patriotism-based courses. NGT is a suitable method in determining the priority level of ideas from the participants in interpreting a situation. The participants consisted of eight students from Universiti Putra Malaysia (UPM) and eight students from Universiti Pendidikan Sultan Idris (UPSI). All the participants were students who had already taken patriotism-based courses such as Malaysian Nationhood, Malaysian Studies and Ethnic Relations. The participants were to discuss the appropriate teaching and learning methods that attract students to patriotism-based courses. The participants were selected by purposive sampling.

Generally in NGT activities, participants are given the opportunity to speak up and share their views and ideas on some scenario. Their ideas and suggestions are shared and viewed by all the participants by writing on a paper, and explaining to them in the form of a round-robin or take turns method. Then, their ideas and views will be discussed clearly. In this process, the 
same idea will be combined. Next, each option will be determined by its priority through the ranking process. Finally, after the second ranking process is implemented, the ten ideas that have been given the highest ranking will be discussed again to obtain the consent of each of the participant. The qualitative data that have been collected through NGT will be analyzed based on a predetermined ranking. Once the NGT is carried out, the data that have been obtained will be used to form a construct in the questionnaire through the quantitative method. In this case, the quantitative methods through a survey technique are important to be carried out, so that the data can be generalized in a wider group. The survey has involved 400 respondents from UPM and 400 respondents from UPSI. The determination of the number of respondents is to meet the average standard of setting the sample size as has been proposed by Krejcie and Morgan (1970). Therefore, the total number of respondents who have been involved is 800 . Accordingly, the stratified sampling technique has been used to determine the samples of this study. Finally, the findings are analysed descriptively based on the percentage values in order to identify the teaching and learning methods that can attract students to patriotism-based courses. Then the findings will be categorised according to the appropriate teaching and learning approach.

\section{Findings and Discussion}

Based on the demographic aspects, it was found that the number of respondents from the UPM and UPSI was almost balanced, representing 49.7 percent and 50.3 percent respectively. The respondents from non-social science faculties are found to be more numerous than the respondents from the faculty of social science, which is 75 percent and 25 percent. However, this does not affect the feedback that is given in this questionnaire as they have attended courses that are related to Malaysian nationhood previously. In terms of gender, female respondents have outnumbered the male respondents by 72.7 percent and 27.3 percent. The majority of the respondents were second year students (42.4 percent). This has been expected because the respondents criteria are those who have taken courses that are related to Malaysian nationhood. This aspect is important to be taken into account to ensure the accuracy of the feedback that is given.

Table 1: Respondent Demographics

\begin{tabular}{llcc}
\hline Bil. & ITEM & DETAILS & PERCENTAGE \\
\hline 1. & Institution & UPM & 49.7 \\
& & UPSI & 50.3 \\
& & TOTAL & 100 \\
\hline 2. & Faculty & Social Science & 25 \\
& & Non Social Science & 75 \\
& & TOTAL & 100 \\
\hline $3 . \quad$ Gender & Male & 27.3 \\
& & Female & 72.7 \\
& & TOTAL & 100 \\
\hline 4. & Year of study & First year & 25.7 \\
& & Second year & 42.4 \\
& & Third year & 21 \\
& & Fourth year & 9.8 \\
& & Others & 1.1 \\
& & TOTAL & 100 \\
\hline
\end{tabular}


Table 2 shows that most of the respondents have agreed on the items that are asked in the questionnaire, which are related to teaching methods that could attract students to patriotism-based subjects. The highest percentage is seen in the statement 'Group activities in the classroom should involve multi-ethnic students', which is at 96.7 percent. This response shows the level of awareness among the respondents on the importance of fostering unity among the multi-ethnic community. This illustrates that the patriotism-based courses has been sucessfully appreciated by them.

Table 2: Teaching and Learning Methods To Attract Students To Patriotism-Based Courses

\section{STATEMENT} PERCENTAGE (\%)

Agree Disagree

1. Group activities in the classroom should involve multi-ethnic students $96.7 \quad 3.3$

2. Encouraging students to relate the historical facts with the current $95.6 \quad 4.4$ issues during teaching and learning sessions

3. Having more discussion in the classroom on current affairs $95.2 \quad 4.8$

4. Lecturers need to clarify current issues of the country in the 95.1 classroom

5. Organizing patriotism exhibitions

$94.9 \quad 5.1$

6. Having role play activities based on patriotism theme in the

7. Visiting the historical places (Kota Melaka, museums etc.)

$94.3 \quad 5.7$

8. Watching patriotic themed video

9. Visiting the institutions of nationhood (such as Parliament, the courts,

10. invasion government agencies etc.) Interviewing the Malaysian heroes about their experiences during the

93.4

11. Organizing a patriotism-based musical performance

12. Organizing a patriotism-based debate

Collecting historical information of our country verbally from those

92.9

13. who experienced

14. Lecturers need to prepare patriotism-based quizzes for students

$92.6 \quad 7.4$

Organizing community service activities (cleaning the public areas,

92.0

8.0

15. carry out social work, cleaning the public toilets etc.)

16 Organizing essay writing contest on patriotism

$91.5 \quad 8.5$

17. Using the picture of historical figures for classroom activities

18. Creating logo for the Independence Day celebration

19. Organizing a patriotism-based poetry

20. Organizing a patriotism-based online forum

$89.1 \quad 10.9$

The 20 statements in Table 2 are classified into the appropriate teaching and learning approaches. Thus, six teaching and learning approaches have been developed from these questions, they are the teacher-centered, student-centered, interactive, constructivist, collaborative and indirect as tabulated in Table 3 . The teacher-centered approach is a conventional teaching approach where the lecturer plays an important role in conveying information about a particular subject. This approach can only be seen through statement 4 which describes the role of the lecturers in explaining current issues that occur in the country to the students. Although education in the 21st century is more centered on the students 
(Siong and Kamisah, 2018), respondents still feel that teacher-centered learning is still needed to attract students to subjects that are often considered as boring. This can be proven when 96.7 percent of respondents have agreed with the statement. This situation shows that in certain circumstances a regular teacher-centered approach is required to describe a new scenario for the student. However, this approach can be developed to be interactive and as student-centered approaches if the lecturer wants to test the level of understanding among the students about something that he has described, for example through a quiz and reflection activities.

Table 3: Classification of Teaching and Learning Approach Based on Statements in Table 2

\begin{tabular}{|c|c|c|c|c|c|c|c|c|c|c|c|c|c|c|c|c|c|c|c|c|c|}
\hline & & \multicolumn{20}{|c|}{ ITEM (FINDINGS) } \\
\hline & APPROACH & 1 & 2 & 3 & 4 & 5 & 6 & 7 & 8 & 9 & $\begin{array}{l}1 \\
0\end{array}$ & $\begin{array}{l}1 \\
1\end{array}$ & $\begin{array}{l}1 \\
2\end{array}$ & $\begin{array}{l}1 \\
3\end{array}$ & $\begin{array}{l}1 \\
4\end{array}$ & $\begin{array}{l}1 \\
5\end{array}$ & $\begin{array}{l}1 \\
6\end{array}$ & $\begin{array}{l}1 \\
7\end{array}$ & $\begin{array}{l}1 \\
8\end{array}$ & $\begin{array}{l}1 \\
9\end{array}$ & $\begin{array}{l}2 \\
0\end{array}$ \\
\hline 1. & $\begin{array}{l}\text { Teacher- } \\
\text { centered }\end{array}$ & & & & & & & & & & & & & & & & & & & & \\
\hline 2. & $\begin{array}{l}\text { Student - } \\
\text { centered }\end{array}$ & & & & & & & & & & & & & & & & & & & & \\
\hline 3. & Interactive & & & & & & & & & & & & & & & & & & & & \\
\hline 4. & Constructivist & & & & & & & & & & & & & & & & & & & & \\
\hline 5. & Collaborative & & & & & & & & & & & & & & & & & & & & \\
\hline 6. & Indirect & & & & & & & & & & & & & & & & & & & & \\
\hline
\end{tabular}

The student-centered approach can be traced through 15 statements that are numbered$1,2,3,5,6,10,11,12,13,15,16,17,18,19$ and 20 . The student-centered approach puts trust in the students' ability to share things during the teaching and learning process as they are also a key resource in the process (Hoque, 2016). The findings showed that more than 89 percent of respondents agreed that group activities, discussions, exhibitions, role play, interview, debate, community service, organizing contest, forum and musical performance can attract students to patriotism-based courses. Zolkefli et al (2019) pointed out that students in the 21st century were found to be more likely to study hands-on and be engaged in classroom activities compared to conventional methods. This is because a student-centered approach can reduce the students' boredom of a subject because the teachers engage them directly in the teaching and learning process.

Interactive approaches in teaching and learning can be researched through statement numbers 2,3,5,6,12,14 and 20. This approach refers to hands-on student activities to form student engagement through guided social interaction (Australian National University, n.d). The results showed that over 89 percent of respondents agreed that discussion activities, brainstorm on current issues to solve problems, organize exhibitions and forums, role play, debate, quizzes can attract students to patriotism-based courses. Since younger generation nowadays are more likely to use electronic gadgets such as the smartphones, iPad, laptops and tablets in everyday life, as such this interactive approach is expected to attract more students if they use the appropriate applications such as padlets, wordwall, mentimeter, kahoot, quizzes and so on in the teaching and learning activities.

Besides that, statements of $5,7,8,9,10,13$ and 15 can be classified as constructivist approaches. This approach refers to a learning process that explains how knowledge is 
structured in the mind of the student. Knowledge is actively developed by the student himself and is not passively accepted from his environment. This means that the learning is the result of the student's own efforts and is not transferred from the teacher to student. Thus, this no longer adheres to the old concept of teaching and learning, where the teachers simply transfer knowledge to pupils without the student himself trying and using his existing experience or knowledge (Yahya and Ayles, 2011). In other words, the approach provides an opportunity for the students to develop skills and knowledge by linking past experiences with future uses (Hoque, 2016). In order to apply this approach, the elements that make up the past experience need to be created first. Thus, statements involving activities that form past experience through this questionnaire statement such as exhibition and community service organizing, visiting, watching videos and interviews of national heroes can be seen to help in attracting students' patriotism-based courses, thus reducing their boredom towards the subject. This can be proven when more than 90 percent of the respondents have agreed with the statement. When students are exposed to the experience first, they will subsequently have the knowledge to work on new ideas and then will be able to actively develop them during classroom activities.

Collaborative approach can be seen through statements numbered 5,6,7,9,11,12 and 15 . More than 90 percent of the respondents agreed that the elements of collaborative learning through group activities when organizing an event can help to attract students to patriotismbased courses. Collaborative means a situation where there is an element of consensus and tolerance between individuals or parties in order to produce something effective. Thus, collaborative learning is a method in which a group of students collaborate and work together to conduct learning activities with peer guidance in order to move towards one goal. Students need to be two or more in one group to work together to solve problems, complete tasks, or to learn new concepts (Knowledge Hub, 2019).

In addition, statements 5,11,12,15,16,19 and 20 may also be categorized in the indirect approach. This approach emphasizes the use of inquiry in the student's learning process that is facilitated by the teachers indirectly. In this case, the indirect approach encourages higher order thinking skills in an environment that encourages problem-solving and project-based learning. There are three main steps to be implemented in this type of teaching and learning approach, namely (Ruutmann and Kipper, 2018):

a. advanced organizers - provide a diagram of whatever a lecturer is trying to explain. The diagram helps the students to organize and process the information they are seeing. Advanced organizers are indirectly explaining content through the diagrams they provide.

b. student self-evaluation - allows the students to assess their performance on a particular assignment or project. As the student judges their own progress, they learn what they are doing and try to make some improvements, while the lecturer's role is to provide hints as to what may be some of the student's problems.

c. group discussion - allows the students to share opinions on a concept or idea with or without the guidance of the lecturer. The purposes of this step are to understand a concept, engage the students, develop communication, and contribute to deeper thinking processes. If the teacher is involved, he or she will serve as a facilitator who provides a conducive environment for discussion as well as contributing to the discussion. 
Accordingly, based on the statement in Table 2, indirect approaches can be found to attract students to a patriotism-based course because there is an element of soft skill as an added value that the students need to master through organized projects such as critical thinking, leadership and team work skills. This can be proven when more than 89 percent of the respondents supported the statement.

\section{Conclusion}

Strengthening patriotism among the younger generation through a formal education medium can be successfully implemented if the teaching and learning approach that is used by the educators can attract students to patriotism-based subjects. Ideally, the approach that is discussed in this paper has its own specialty in enriching the soft skills of the students and is expected to reduce boredom towards subjects that they lack interest in, if it is carried out accordingly. Hence, it is hoped that the speciality will motivate them to focus on patriotismbased courses properly. This is because there are some students who take for granted these compulsory courses.; they learn just to pass the examination without appreciating the contents of the course. This situation is one of the barriers in strengthening patriotism among the younger generation. In this context, if a student is mentally matured and far-sighted, they will feel that such courses can add to their personal value through the enrichment of soft skill elements such as decision-making skills, leadership, teamwork, communication and so on. These elements are helpful and are very important for each student to master in order for him or her to achieve his or her dreams. If they are able to appreciate the patriotism-based course well, naturally, they will be good citizens who will serve their country wholeheartedly

\section{Acknowledgement}

This research sponsored by Incentive Grant for Research in Teaching and Learning, Universiti Putra Malaysia (UPM/GIPP/9323662).

\section{References}

Ahmad, T. T., Gill, S. S., Mahadee, M. I., Jayum, J., \& Zaid, A. (2010). Gagasan 1Malaysia dan semangat patriotisme belia Program Latihan Khidmat Negara (PLKN). Malaysian Journal of Youth Studies, 2, 142-158.

Aishah, N. Z., Mohd, A. M. S., \& Wan, A. W. M. (2020). Impak Media Baharu Terhadap Patriotisme Belia di Malaysia. Jurnal Personalia Pelajar, 23(1), 1-6

Australian National University. (n.d). What is interactive learning. https://services.anu.edu.au/learning-teaching/course-design-help/interactivelearning-0/what-is-interactive-learning

Azizah, N. M. (2019). Polis siasat kes silap bendera Malaysia. Berita Harian. https://www.bharian.com.my/berita/kes/2019/11/632182/polis-siasat-kes-silapbendera-malaysia

Berns, W. (1997). On Patriotism. Public Interest, Spring: 19.

Chu, J., \& Couper, D. P. (2003). The Flag and Freedom. Social Education, 67(6), 327.

Curti, M. (1946). The roots of American loyalty. Columbia University Press.

Diyanatul, A. Z. (2021). Komunis: Restoran terkenal di Melaka pula diserbu. Utusan Malaysia. https://www.utusan.com.my/berita/2021/01/komunis-restoran-terkenal-di-melakapula-diserbu/

Eggen, P. D., \& Kauchak, D. P. (1993). Strategies for Teachers. Teaching Content and Thinking Skills. Allyn and Bacon:USA. 
Gehring, J. (2002). States weigh bills to stoke students' patriotism. Education Week, 21.

Hairul, M. A. R., Jayum, J., Adlina, A. H., Mahadee, M. I., \& Siti, A. M. (2013). Penghayatan dan kesedaran patriotisme dalam kalangan pelatih Program Latihan Khidmat Negara. Malaysian Journal of Youth Studies, 8(6), 1-24.

Hoque, M. E. (2016). Teaching approaches, methods, and techniques [PowerPoint]. University of English and Foreign Languages. https://www.researchgate.net/publication/315836577_ Teaching_Approaches_Methods_and_TechniquesEnamul_Hoque/link/ 58eb322daca2729d8cd5a24d/download

Johnson, A. G. (2000). The Blackwell Dictionary of Sociology. Blackwell Publishers.

Karlin, M. S. (1975). Classroom Activities Desk Book for Fun and Learning. Parker Publishing Company.

Knowledge Hub. (2019). What is collaborative learning? https://www.valamis.com/hub/collaborative-learning

Ku Hasnita, K. S., \& Mohd, H. M. N. (2011). Kepentingan pendidikan patriotisme terhadap warganegara malaysia (the importance of patriotic education for malaysian citizens). Jati-Journal of Southeast Asian Studies, 16, 23-34.

Ku Hasnita, K. S., Zatul, H. A., Mahadee, M. I., Lee, Y. F., Arfah, A. M., \& Ratna, R. R. A. R. (2020). Pendirian Generasi Muda Terhadap Penggunaan Bahasa Melayu Sebagai Wadah Patriotisme di Malaysia. Jurnal Sains Insani, 5(2), 17-24. https://doi.org/10.33102/sainsinsani.vol5no2.205

Mahadee, M. I., Mohd, S. A., \& Mansor, M. N. (2014). Signifikan implementasi Program Latihan Khidmat Negara (PLKN) di Malaysia. Jurnal Kinabalu, 20, 147-175.

Manzo, K. K. (2001). Education experts expect resurgence of patriotism in nation's classroom. Education Week, 21(4), 10.

Motyl, A. J. (Ed.) (2001). Encyclopedia of Nationalism: Leaders, Movements and Concepts. Vol 2. Academic Press.

Nussbaum, M. C. (2012). Teaching Patriotism: Love and Critical Freedom. University of Chicago Law Review, 79(1), 213-248. https://chicagounbound.uchicago.edu/uclrev/vol79/iss1/9

Primoratz, I. (2002). Patriotism: A deflationary view. In The philosophical forum, 33(4), 443458.

Abdul Hamid, R. (2018). PLKN, BTN dibubar serta merta - Syed Saddiq. Berita Harian. https://www.bharian.com.my/berita/nasional/2018/08/461275/plkn-btn-dibubarserta-merta-syed-saddiq

Ruddin, M., Shamsuri, M., \& Albert, F. (2005). Peningkatan Patriotisme dalam Kalangan Belia / Pelajar IPTA: Kajian Kes KUTKM. dlm H. Mohammad, Belia \& Patriotisme Malaysia (100-111). Melaka: Institut Kajian Sejarah dan Patriotisme Malaysia (IKSEP).

Abdullah, S. (2005), Patriotisme alaf baru. Dlm Hussain Mohamad (pnytg.). Belia dan patriotisme Malaysia, hlm. 70-93, Melaka: Institut Kajian Sejarah dan Patriotisme Malaysia.

Ismail, S. (1995). Peranan Matapelajaran Sejarah dalam Membentuk Masyarakat Berwawasan. (Pembentangan kertas kerja). Konvensyen Guru Sejarah Peringkat Negeri Sarawak. Malaysia.

Siong, W. W., \& Osman, K. (2018). Pembelajaran Berasaskan Permainan dalam pendidikan STEM dan penguasaan kemahiran abad ke-21. Politeknik \& Kolej Komuniti Journal of Social Sciences and Humanities, 3(1), 121-135. 
Suraya, R. (2019). Isu bendera: Memang sengaja dilakukan - Teo Kok Seong. Harian Metro. https://www.hmetro.com.my/utama/2019/11/520970/isu-bendera-memang-sengajadilakukan-teo-kok-seong

Tengku, K. A R. (2015). Indeks patriotisme pupuk keharmonian bermasyarakat. Berita Harian Online. http://www.bharian.com.my/node/33539

Vail, K. (2002). Best uses for the new student patriotism. Education Digest, 67, 8-11.

Wan, M. N. W. D. (2015). Patriotisme adil di zaman global. In Muhammad Zainiy Uthman (ed). Bunga rampai bangsa, kebangsaan dan patriotisme. CASIS UTM.

Wan Mokhtar. (2015). Jati diri seorang guru. SCRIBD. https://www.scribd.com/doc/283596399/Jati-Diri-Seorang-Guru

Yahya, B., \& Amirudin, Y. (2011). Pendekatan Pembelajaran Secara Konstruktivisme Dalam Kalangan Guru-Guru Teknikal Bagi Mata Pelajaran Teknikal. https://core.ac.uk/download/pdf/11785848.pdf

Yong, S. L. (2013). Gabungan Pendekatan Konstruktivisme Dan Behaviorlisme Bagi Meningkatkan Prestasi Mata Pelajaran Sejarah Tingkatan Tiga (Paper presentation). Seminar Pendidikan Sejarah Dan Geografi, UMS, Malaysia. 